\title{
Studi Keandalan Motor Induksi Tiga Fasa Main Drive Finish Mill 4.1 PT. Semen Tonasa
}

\author{
A Fadhiil Apriansyah $\mathbf{Z}^{\mathbf{1}}$, Ahmad Rizal Sultan ${ }^{2)}$ \\ Teknik elektro, Politeknik Negeri Ujung Pandang \\ email :fadhilapriansyah1@gmail.com ${ }^{1)}$,rizal.sultan@poliupg.ac.id ${ }^{2}$
}

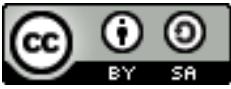

Abstrak

Dalam pengoperasian motor induksi 3 fasa diperlukan pengecekan dan pemeriksaan yang disebut maintenance dimaksudkan sebagai tindakan untuk mencegah dan memperbaiki kerusakan yang menjamin tingkat keandalan, dari penelitian penulis menemukan hasil efficiency tingkat keandalan yang memenuhi standarisasi perusahaan dan yang tidak, serta gangguan yang terjadi diantaranya disebabkan oleh bearing rusak, lilitan motor terbakar,serta saluran pendingin / kipas motor tidak berfungsi dan gangguan itu diatasi dengan adanya jadwal perawatan secara mingguan, bulanan, tahunan

Keywords: maintenance, efficiency, motor, grafik, periode

\section{PENDAHULUAN}

PT. Semen Tonasa adalah produsen semen terbesar di kawasan timur Indonesia yang menempati lahan seluas 1.200 hektar di Desa Biringere Kec. Bungoro Kab. Pangkep, sekitar 68 $\mathrm{km}$ dari kota Makassar. Mulai didirikan pada tanggal 05 Desember 1960, dan PT. Semen Tonasa memiliki kapasitas terpasang 5.980.000 ton semen pertahun terdiri dari 4 unit pabrik yang beroperasi, yaitu pabrik unit II/III dengan kapasitas 590.000 ton semen pertahun, pabrik unit IV dengan kapasitas 2.300.000 ton semen pertahun yang mulai beroperasi sejak tahun 1996, dan pabrik unit $\mathrm{V}$ dengan kapasitas 2.500 .000 ton semen pertahun. Dalam hal ini peneliti bertempat di unit 4 bagian finish mill, dimana target ptoduksi yang hendak dicapai cukup tinggi yaitu sekitar 1.658.880 ton semen / tahun. Maka dari itu sangatlah melibatkan mesin dalam proses produksinya, dengan kondisi seperti itu, perlu diberlakukan proses maintenance ( pemeliharaan ) yang tepat pada tiap mesin dan produktfitas mesin dituntut untuk baik dan lancar dari segi operasionalnya, Hal ini bertujuan untuk mendapatkan produksi yang optimal agar bisa memenuhi permintaan konsumen pelanggan.

Perusahaan harus dapat mempertahankan keandalan mesin produksi supaya dapat memenuhi target produksinya. Keandalan mesin dapat dipertahankan dengan menerapkan sistem manajemen pemeliharaan yang direncanakan dan dilakukan dengan baik. Untuk itulah maka perlu dilakukan suatu kemajuan (improvement) agar sistem dapat lebih andal lagi dalam mencapai tingkat keandalan dan tidak terjadi masalah masalah yang tidak diinginkan sehingga dapat mengakibatkan kerugian pada perusahaan, maka penulis akan mengadakan penelitian dengan judul
"Studi Keandalan Motor Induksi 3 Fasa pada Main Drive Finish Mill 4.1 PT. Semen Tonasa".

\section{METODE PENELITIAN}

Metode peulisan jurnal ini dilakukan dengan beberapa metode yaitu survei, wawancara, studi literatur dan dokumentasi. Secara singkat ditunjukkan pada diagram alir penelitian adalah sebagai berikut.

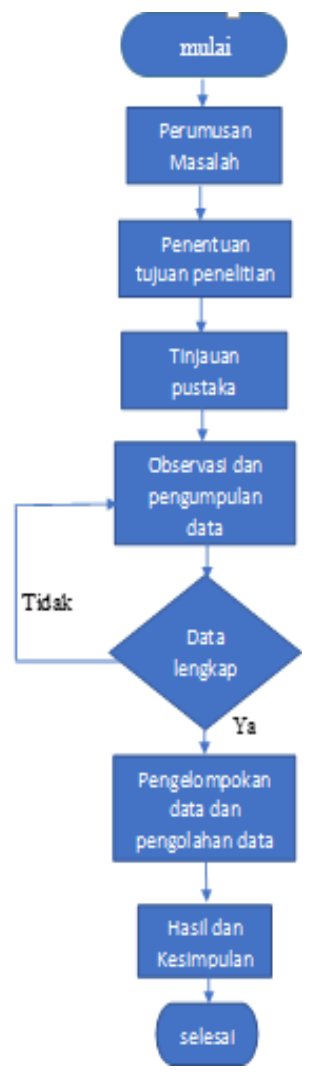

Gambar 1.Metode Penelitian 


\section{HASIL DAN PEMBAHASAN}

A. Jenis Pemeliharaan pada Motor Induksi Tiga Fasa

Tindakan pemeliharaan yang dilakukan pada motor induksi tiga fasa adalah sebagai berikut :

1. Tindakan Pemeliharaan Harian

Merupakan tindakan pemeliharaan rutinitas yang dilaksanakan para personel setiap hari yang meliputi : pembersihan, pengecekan sensor, dan pelumasan.

2. Tindakan Pemeliharaan Mingguan

Merupakan tindakan pemeliharaan tingkat yang dilakukan secara periodic atau dilakukan secara berkala yaitu tepatnya dilaksanakan setiap satu minggu sekali oleh para personel yang meliputi kegiatan - kegiatan pengecekan terhadap daya kerja suatu mesin.

3. Tindakan Pemeliharaan Berat (Pemeliharaan Overhaul)

Merupakan tindakan pemeliharaan tingkat berat yang bersifat kontinu, dilakukan overhaul, perbaikan mesin total.

Dengan adanya pemeliharaan yang baik dan dilakukan secara teratur maka akan membuat mesin dapat beroperasi dengan optimal dan kualitas produk juga akan lebih baik

B. Perhitungan Indeks Keandalan Motor Induksi Tiga Fasa

Perhitungan indeks keandalan pada motor induksi tiga fasa dimulai dari bulan januari sampai dengan bulan desember periode 2017 dapat dilihat dibawah ini :

\section{Bulan Januari}

Dengan melihat tabel 1 pada lampiran, dapat diteliti bahwa jumlah kegagalan pada periode bulan januari, sebanyak 24 kegagalan. Dengan menggunakan persamaan 4 maka diperoleh :

Laju kegagalan $(\lambda)$

$\lambda$

$$
\begin{gathered}
=\frac{\text { Jumlah kegagalan sistem pada selang waktu }}{\text { Selang waktu pengamatan (bulan) }} \\
=\frac{24}{1} \\
=24 \text { kegagalan }
\end{gathered}
$$

Waktu kegagalan perbulan (r)

$$
r=6485 \text { menit }
$$

$$
=108.083333 \mathrm{jam} \text { kegagalan perbulan }
$$

Dari hasil perhitungan $\lambda$ (laju kegagalan) dan $r$ (waktu kegagalan perbulan) diatas, dapat diteliti bahwa jumlah waktu kegagalan perbulan pada periode bulan januari,berdurasi 108.083 jam kegagalan dengan 24 kegagalan untuk memperoleh waktu perbaikan. Dengan menggunakan persamaan 5 maka diperoleh :

Waktu perbaikan

$$
\begin{gathered}
t=\frac{r}{\lambda} \\
\frac{108.083}{24} \\
=4,503 \mathrm{jam}
\end{gathered}
$$

$\mathrm{T}=$ Sistem beroperasi 24 jam $\times 31$ hari $=744$ jam

$\%$ Ketidaktersediaan

Dari hasil perhitungan $r$ pada perolehan waktu kegagalan perbulan dan waktu sistem beroperasi, dapat diteliti nilai ketidaktersediaan pada periode bulan januari, Dengan menggunakan persamaan 19 maka diperoleh :

$$
\begin{gathered}
P 1=u \\
=\frac{\text { Waktu tidak beroperasi }}{\text { Waktu operasi }} \times 100 \% \\
=\frac{108,083}{744} \times 100 \% \\
=0,145258064 \times 100 \% \\
=14,525 \%
\end{gathered}
$$

$\%$ Ketersediaan

Dari hasil perhitungan u ( ketidaktersediaan ), dapat diteliti nilai a (ketersediaan) pada periode bulan januari,. Dengan menggunakan persamaan 18 maka diperoleh :

$$
\begin{gathered}
P_{2}=a=(1-U) \times 100 \% \\
=(1-0,145258064) \times 100 \% \\
=0,854741936 \times 100 \% \\
=85,474 \%
\end{gathered}
$$

$\%$ Keandalan

Dari hasil perhitungan u ( ketidaktersediaan ), dapat diteliti nilai keandalan pada periode bulan januari. Dengan menggunakan persamaan 14 maka diperoleh :

$$
\begin{aligned}
& R(t)=e^{-u} \times 100 \% \\
= & e^{-0.864799146} \times 100 \% \\
= & 0,42113613 \times 100 \% \\
= & 42,2 \%
\end{aligned}
$$

C. Analisis Keandalan Sistem Motor Listrik Induksi Tiga Fasa Pada PT. Semen Tonasa Unit 4

Berdasarkan data hasil operasi yang telah diperoleh selama satu tahun terakhir dimulai sejak bulan Januari - Desember 2017 maka dapat diadakan perhitungan indeks keandalan untuk sistem tersebut diatas, yang hasilnya telah dibuat 
dalam bentuk tabel - tabel dan grafik - grafik yang dapat dilihat dibawah ini.

\begin{tabular}{cccc}
\hline NO & Bulan & $\begin{array}{c}\text { Laju } \\
\text { Kegagalan } \\
(\boldsymbol{\lambda})\end{array}$ & $\begin{array}{c}\text { Waktu } \\
\text { Beroperasi } \\
\text { (hari) }\end{array}$ \\
\hline 1 & Januari & 24 & 31 \\
\hline 2 & Februari & 14 & 28 \\
\hline 3 & Maret & 18 & 31 \\
\hline 4 & April & 29 & 30 \\
\hline 5 & Mei & 17 & 31 \\
\hline 6 & Juni & 21 & 30 \\
\hline 7 & Juli & 15 & 31 \\
\hline 8 & Agustus & 18 & 31 \\
\hline 9 & September & 20 & 30 \\
\hline 10 & Oktober & 10 & 31 \\
\hline 11 & November & 24 & 30 \\
\hline 12 & Desember & 13 & 31 \\
\hline
\end{tabular}

Dari hasil penunjukan tabel dibawah terlihat perbedaan kegagalan yang terjadi di setiap periode-nya, maka dapat dilihat secara jelas dengan menampilkan grafik yang dapat kita lihat pada bagian dibawah ini.

Tabel Nilai Hasil Perhitungan Laju Kegagalan $(\lambda)$ dan Waktu Beroperasi ( Hari ) Motor Induksi 3 Fasa Periode Tahun 2017

Tabel 1. Laju Kegagalan $(\lambda) \&$ Waktu Beroperasi ( hari )

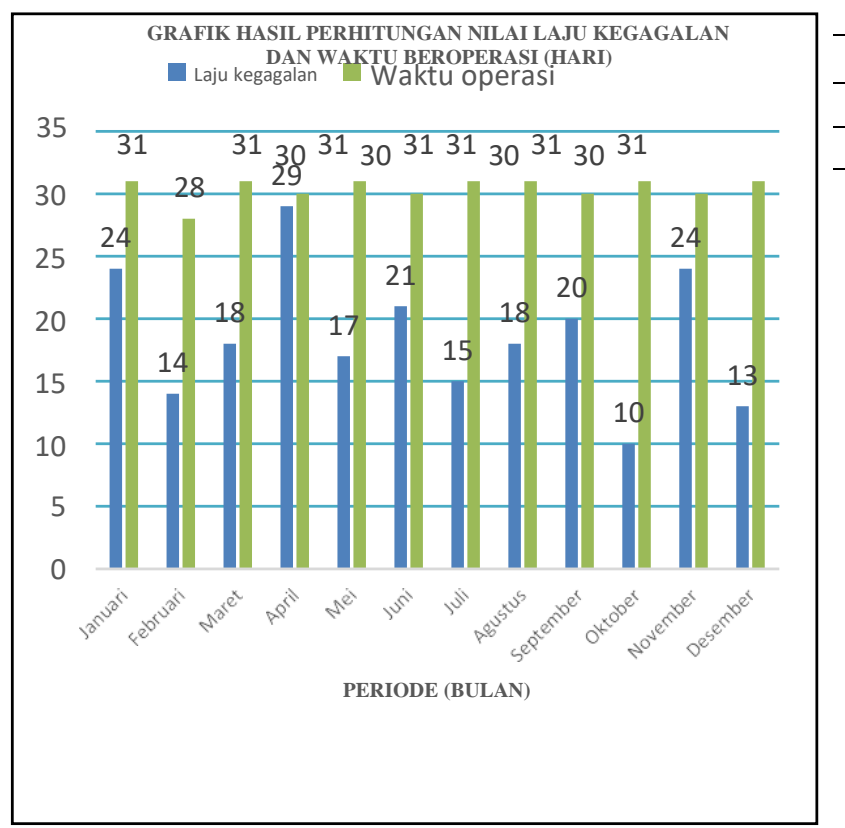

Gambar 1. Hasil Perhitungan Nilai Laju Kegagalan dan Waktu Beroperasi (hari)

Dengan menyimak pada tabel 3 dan grafik 4.2 ( hasil perhitungan laju kegagalan $(\lambda)$ dan waktu beroperasi ( hari ) motor induksi 3 fasa periode tahun 2017 ), dapat dianalisa dengan seksama bahwa tabel dan batang grafik menunjukkan laju kegagalan ( $\lambda$ ) yang tertinggi terjadi pada bulan april, yaitu mencapai 29 kali dengan waktu operasi berdurasi 1 bulan ( 30 hari ), yang telah diperoleh dari jumlah kegagalan sistem pada suatu selang waktu ( 29 kali ) dibagikan dengan selang waktu pengamatan ( bulan ) 1 . Hal ini juga dikarenakan pada bulan april seringnya terjadi gagal start, sedangkan tabel 3 dan batang grafik 4.2 menunjukkan bulan oktober adalah laju kegagalan $(\lambda)$ terendah yang mencapai hanya 10 kegagalan dalam durasi 1 bulan ( 31 hari ).

Tabel Nilai Hasil Perhitungan Waktu Kegagalan Dan Waktu Perbaikan

Tabel 2. Waktu Kegagalan dan Waktu Perbaikan

\begin{tabular}{cccc} 
NO & Bulan & $\begin{array}{c}\text { Waktu } \\
\text { Kegagalan } \\
\text { Perbulan } \\
\text { (jam) }\end{array}$ & $\begin{array}{c}\text { Waktu } \\
\text { Perbaikan } \\
\text { (jam) }\end{array}$ \\
\hline 1 & Januari & 108,083 & 4,503 \\
\hline 2 & Februari & 62,2 & 4,442 \\
\hline 3 & Maret & 79,483 & 4,415 \\
\hline 4 & April & 112,5 & 3,873 \\
\hline 5 & Mei & 85,75 & 5,044 \\
\hline 6 & Juni & 79,15 & 3,769 \\
\hline 7 & Juli & 69,083 & 4,605 \\
\hline 8 & Agustus & 48,883 & 2,715 \\
\hline 9 & September & 50,1 & 2,505 \\
\hline 10 & Oktober & 62,35 & 6,235 \\
\hline 11 & November & 89,66 & 3,735 \\
\hline 12 & Desember & 45,15 & 3,473 \\
\hline
\end{tabular}

Dari hasil penunjukan table diatas menjelaskan antara waktu kegagalan yang terjadi (sistem berhenti beroperasi) beserta lama waktu yang dibutuhkan untuk mengatasi atau memperbaiki hingga sistem dapat bekDari hasil penunjukkan tabel diatas menjelaskan antara waktu kegagalan yang terjadi (sistem bererja kembali dengan normal, untuk lebih jelasnya dapat diperhatikan pada grafik yang ada dibawah ini. 


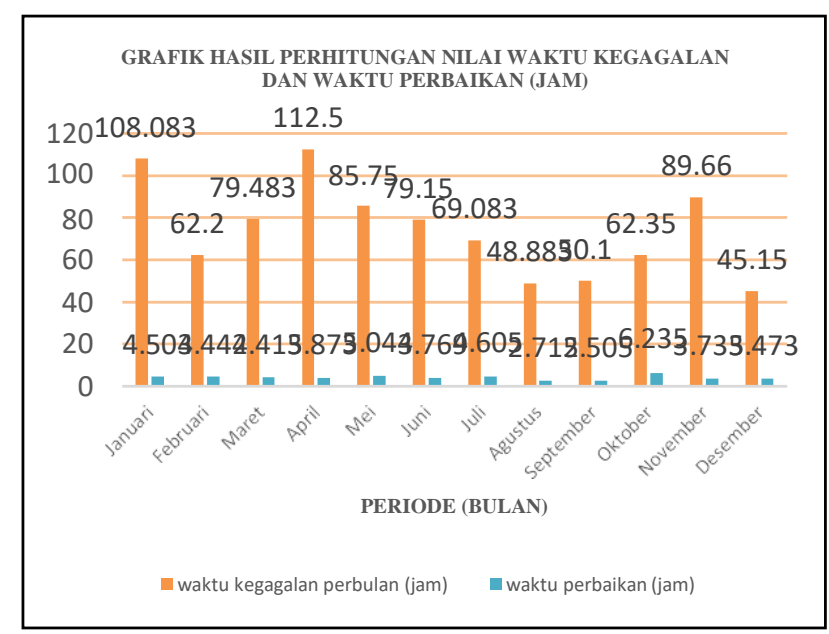

Gambar 2. Hasil Perhitungan Nilai Waktu Kegagalan \& Waktu Perbaikan (Jam)

Dengan menyimak tabel 4 dan grafik 4.3 ( hasil perhitungan kegagalan perbulan ( jam ) dan waktu perbaikan (jam ) motor induksi 3 fasa periode tahun 2017 ), dapat dianalisa dengan seksama bahwa pada bulan januari tabel dan batang grafik menunjukkan waktu kegagalan perbulan ( jam ) yang tertinggi yaitu mencapai 108,083 jam dalam waktu 31 hari, dan membutuhkan waktu perbaikan 4,503 jam yang diperoleh dari waktu kegagalan perbulan ( $\mathrm{r}$ ) 108,083 jam dibagikan dengan jumlah laju kegagalan $(\lambda) 24$. Hal ini dikarenakan pada bulan januari seringnya terjadi kenaikan temperatur $100^{\circ} \mathrm{C}$ hingga terkadang membutuhkan waktu hingga 18 jam/hari untuk mengatasi atau menunggu temperatur normal kembali, dan juga laju kegagalan ( $\lambda$ ) yang tidak sedikit yang ditunjukkan pada tabel 3 dan grafik 4.2 yaitu sebanyak 24 kegagalan dalam waktu 31 hari, sedangkan tabel 4 dan batang grafik 4.3 menunjukkan bulan desember adalah waktu kegagalan perbulan ( jam ) terendah yang cukup jauh dari selisih bulan januari, yaitu sebesar 45,15 jam dalam durasi waktu 31 hari dan dari hasil perhitungan pembagian waktu kegagalan perbulan ( $\mathrm{r}$ ) 45,15 dengan jumlah laju kegagalan $(\lambda)$ menghasilkan waktu perbaikan 3,473 jam.

Tabel Nilai Hasil Perhitungan U (\%), A (\%), dan R (\%) Motor Induksi 3 Fasa Periode Tahun 2017

Tabel 3. Hasil Perhitungan U ( \% ), A ( \% ), dan R ( \% )

\begin{tabular}{ccccc}
\hline NO & Bulan & $\mathbf{U}(\boldsymbol{\%})$ & $\mathbf{A}(\boldsymbol{\%})$ & $\mathbf{R}(\boldsymbol{\%})$ \\
\hline 1 & Januari & 14,525 & 85,5 & 42,2 \\
\hline 2 & Februari & 9,255 & 90,8 & 91,2 \\
\hline 3 & Maret & 0,106 & 89,4 & 89,9 \\
\hline 4 & April & 0,156 & 84,4 & 85,6 \\
\hline 5 & Mei & 0,115 & 88,5 & 89,2 \\
\hline 6 & Juni & 0,109 & 89,1 & 89,6 \\
\hline 7 & Juli & 0,092 & 90,1 & 91,2 \\
\hline
\end{tabular}

\begin{tabular}{ccccc}
\hline 8 & Agustus & 0,065 & 93,5 & 93,7 \\
\hline 9 & September & 0,069 & 93,1 & 93,3 \\
\hline 10 & Oktober & 0,083 & 91,7 & 92 \\
\hline 11 & November & 0,124 & 87,6 & 88,3 \\
\hline 12 & Desember & 0,060 & 94 & 94,2
\end{tabular}

Dari hasil penunjukkan tabel diatas, dimana $\mathrm{U}(\%) \quad$ ketidaktersediaan, $\quad \mathrm{A}(\%)$ ketersediaan, dan $\mathrm{R}(\%)$ keandalan telah terhitung dari bulan januari - desember 2017. Maka kita dapat menampilkan sebuah grafik dengan memasukkan nilai - nilai yang ada, grafik tersebut dapat kita lihat dibawah ini.

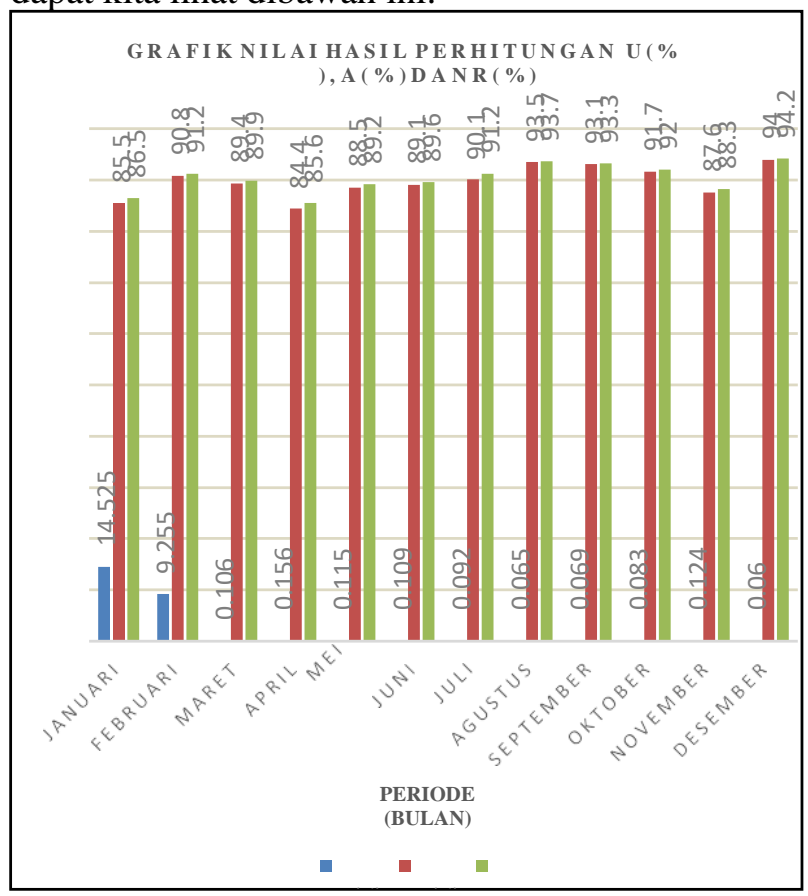

Gambar 3. Grafik Hasil Perhitungan U ( \% ),A ( \% ), R ( \%)

Dengan menyimak pada tabel 5 dan grafik 4.4 ( hasil perhitungan $\mathrm{U}(\%)$, A ( \% ), dan R ( \%) motor induksi 3 fasa periode tahun 2017 ), dapat dianalisa dengan seksama bahwa pada bulan januari tabel dan batang grafik menunjukkan $\mathrm{U}$ ( $\%$ ) ketidaktersediaan yang tertinggi hanya mencapai $14,525 \%$ dalam satu bulan ( 31 hari ), dan U ( \% ) ketidaktersediaan yang terendah dalam satu tahun terlihat pada bulan desember ( 31 hari ) yaitu 0,060 $\%$ yang diperoleh dari waktu tidak beroperasi dibagikan waktu operasi dan dikalikan $100 \%$, sedangkan untuk A ( \% ) ketersediaan dan R ( \%) keandalan tabel 5 dan batang grafik 4.4 menunjukkan A ( \%) dan R ( \% ) tertinggi yang terjadi ditahun 2017 terjadi pada bulan desember, hingga mencapai tinggi yaitu sekitar $94 \%$, sedangkan yang terendah ditunjukkan pada bulan april yaitu sebesar $85 \%$ dibawah analisa tertinggi yang terjadi pada bulan desember. Ini menjelaskan bahwa hasil perhitungan terlihat jelas bahwa antara 
ketersediaan A ( \% ) dan keandalan R ( \% ) ternyata ada yang memenuhi syarat keandalan ( efficiency ) dan ada beberapa bulan juga yang tidak memenuhi, dimana syarat dari keandalan PT. Semen Tonasa untuk motor induksi 3 fasa yaitu $>90 \%$. meskipun target produksi yang hendak dicapai PT. Semen Tonasa Unit 4 cukup tinggi yaitu sekitar 192 ton / jamnya, yang jika dihitung dalam satu hari (24 jam) akan menghasilkan 4608 ton / hari, dan dalam satu bulan (30 hari) sebanyak 138.240 ton / bulan, tentu itu bukan nilai yang sedikit.

\section{PENUTUP}

A. Kesimpulan

Berdasarkan analisa dan pembahasan yang telah dilakukan pada bab - bab sebelumnya, maka beberapa hal yang dapat dijadikan kesimpulan dari penelitian ini adalah sebagai berikut :

1. Hasil perhitungan keandalan pada sistem motor induksi tiga fasa PT. Semen Tonasa unit 4 dari bulan Januari - Desember 2017, ternyata ada yang memenuhi syarat keandalan ( effeciency) dan ada juga yang tidak memenuhi yakni $>90 \%$ yang telah di standarisasikan PT. Semen Tonasa untuk motor induksi 3 fasa, dan salah satu faktor yang mempengaruhi keandalan motor induksi tiga fasa PT. Semen Tonasa Unit 4 yaitu baiknya sistem pengendali yang digunakan sehingga jika terjadi kegagalan pada sistem dapat segera diatasi.

2. Hasil tabel 1 dengan grafiknya menunjukkan bahwa laju kegagalan $(\lambda)$ tertinggi terjadi pada bulan april yaitu mencapai 29 kegagalan, yang menunda motor dengan durasi 6750 menit ( 112,5 jam ) yang berarti sekitar 4 hari lebih, dan laju kegagalan $(\lambda)$ yang terendah mencapai 10 kegagalan, dengan waktu durasi berhenti motor 3741 menit ( 62,35 jam ) yang berarti sekitar 2 hari lebih. Dan pada tabel 2 dengan grafiknya menunjukkan bahwa waktu kegagalan perbulan (jam) tertinggi terjadi pada bulan januari yaitu mencapai 108,083 jam yang membutuhkan waktu perbaikan dengan durasi 4,503 jam, yang apabila dijumlahkan mencapai total 112,586 jam motor berhenti beroperasi, dan waktu kegagalan perbulan ( jam ) 3,473 jam yang jika ditotal dalam menunda operasi motor dengan durasi 48,623 jam. Serta hasil pada tabel 3 diikuti grafiknya menunjukkan bahwa A ( \% ) ketersediaan dan R (\%) keandalan mencapai hasil yang sangat baik yaitu sekitar 85 $90 \%$, dengan angka tertinggi mencapai $94 \%$, diikuti yang terendah dengan nilai sekitar $85 \%$, sementara U ( \% ) ketidaktersediaan hampir tidak terlihat dalam batang grafik karena yang tertinggi hanya mencapai angka 14,525\% diikuti yang terendah mencapai $0,060 \%$. Dengan menyimak hasil perhitungan akhir dalam jangka satu tahun disetiap bulan-nya terdapat ketidakhandalan dibulan januari, maret, april, mei, juni, november yaitu dibawah $90 \%$ yang telah di standarisasikan PT. Semen Tonasa untuk motor induksi 3 fasa dan yang memenuhi syarat keandalan terdapat dibulan februari, juli, agustus, september, oktober, dan desember.

\section{B. Saran}

Berikut beberapa saran yang dapat menjadi masukan bagi perusahaan atau untuk pengembangan penelitian berikutnya antara lain :

1. Untuk lebih meningkatkan keandalan dari motor induksi tiga fasa, maka perlu diambil tindakan / kebijaksanaan guna menunjang tercapainya target yang diharapkan dengan gangguan atau kerusakan yang terjadi harus diatasi secepat mungkin dengan menyiagakan petugas teknisi yang terampil, cekatan, dan siap siaga.

2. Pencatatan data kegagalan komponen komponen yang lebih kecil perlu dilakukan untuk dapat mengetahui nilai keandalan dari komponen tersebut sehingga dapat dilakukan penggantian / pemeliharaan pencegahan terhadap komponen yang lebih spesifik

3. Menyatukan catatan - catatan buku pemeliharaan dan kegagalan di satu tempat, guna memberikan kemudahan untuk mendapatkan apabila suatu waktu dibutuhkan.

\section{DAFTAR PUSTAKA}

[1] Badan Standar Nasional Indonesia. (2011). Persyaratan Umum Instalasi Listrik (PUIL 2011). Badan Standar Nasional Indonesia.

Baharuddin. (2016).

[2] Analisis Pengaruh Pembebanan terhadap Karakteristik Motor Induksi 3 Fasa. Kendari: Universitas Halu Oleo.

[3] Endrenyi, J. (1978). Reliability Modeling in Electric Power System. New York: A wiley Interscience Publication.

[4] Fauzi, I. (2016). Optimalisasi sistem perawatan dan perbaikan terencana mesin produksi berdasarkan analisis keandalan . Banjarmasin: Universitas Lambung Mangkurat.

[5] H, S. D. (2008). Analisis Starting Motor Induksi Tiga Phasa pada pada PT. Berlian Unggas Sakti . Padang: Universitas Sumatera Utara.

[6] Hasbuan, G. B. (2009). Sistem Pemeliharaan Mesin Press di PT. Multi Mekanika Serasi . Jakarta: Universitas Mercu Buana. 
J, S. (1993). Statistik Teori dan Aplikasi. Jakarta: Erlangga.

Lee, C. (2016). Powertips Microsoft Excel. Indonesia: Gudang Penerbit.

Lee, C. (2017). Microsoft Word ( Step - By - Step ). Indonesia: Gudang Penerbit.

Marthen, K. (1994). Fisika SMU Jilid 2 A. Jakarta: Erlangga.

Politeknik Negeri Ujung Pandang. (2016). Pedoman Penulisan Proposal dan Skripsi Program Diploma Empat (D-4) Bidang Rekayasa dan Tata Niaga. Makassar: Politeknik Negeri Ujung Pandang.

\section{UCAPAN TERIMA KASIH}

Ucapan terima kasih ditujukan kepada Bapak Ilham dan kedua pembimbing saya yang telah membantu mengumpulkan data penelitian sampai penelitian ini dapat terselesaikan. 